Discussion Paper No. 04-65

Stepping In and Out of the

International Market:

Internationalisation of Technology-Oriented

Firms in Germany and the UK

Helmut Fryges

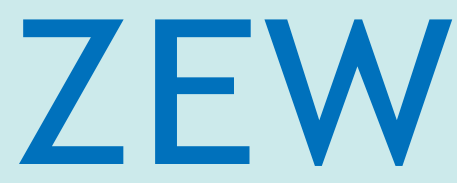

Zentrum für Europäische Wirtschaftsforschung $\mathrm{GmbH}$

Centre for European

Economic Research 
Discussion Paper No. 04-65

\title{
Stepping In and Out of the International Market: Internationalisation of Technology-Oriented Firms in Germany and the UK
}

\author{
Helmut Fryges
}

Download this ZEW Discussion Paper from our ftp server:

ftp://ftp.zew.de/pub/zew-docs/dp/dp0465.pdf

Die Discussion Papers dienen einer möglichst schnellen Verbreitung von neueren Forschungsarbeiten des ZEW. Die Beiträge liegen in alleiniger Verantwortung der Autoren und stellen nicht notwendigerweise die Meinung des ZEW dar.

Discussion Papers are intended to make results of ZEW research promptly available to other economists in order to encourage discussion and suggestions for revisions. The authors are solely responsible for the contents which do not necessarily represent the opinion of the ZEW. 


\section{Non-technical Summary}

In order to fulfil the expectations related to growth and job creation, newly technology based firms (NTBFs) have to achieve continuous long-term growth. It is often argued that sales potential in European domestic markets is insufficient for the amortisation of high product research and development costs, thus long-term international business activities are regarded as decisive for growth perspectives of NTBFs. Numerous studies have investigated the internationalisation process of NTBFs during their start-up period. The present paper extends this restrictive view by examining NTBFs over a longer time period and analysing long-term internationalisation behaviour. The causality between internationalisation and long-term growth (performance) is beyond the scope of this paper. However, understanding the way in which firmspecific characteristics affect the surveyed firms' internationalisation behaviour could help future research explain the oft-observed positive correlation between performance and internationalisation.

This paper examines a sample of German and British NTBFs founded between 1987 and 1996, inclusive. The firms were contacted using two surveys conducted simultaneously in Germany and the UK in 1997 and 2003. More than two-thirds of responding firms had international sales. Although there is a high persistence in the firms' international business activities, we observe entry into and exit from the foreign market. Only 15 per cent of the firms in our sample have never had international sales. The phenomenon of nonpersistent export participation trajectories has already been highlighted by the literature. Analysing empirically long-term international business activities, therefore, requires examining both entry and exit.

A binary-choice non-structural model is applied to identify "hard" success factors that are linked with longterm international business activities. The results show that there are minor differences between German and UK firms with respect to their internationalisation behaviour. Although the existence of sunk entry costs cannot be proved with our data set, the results are consistent with the sunk cost hypothesis. Firms can overcome high entry costs by acquiring firm-specific assets. Similarly, firm-specific resources prevent firms from exiting the foreign market. The strategic role of investment in R\&D is stressed in particular by the data. Moreover, employing internationally experienced managers constitutes an intangible asset that facilitates firms' export activities. If a firm's products or services, however, require high individual client customisation, this presents a barrier to entry into the foreign market and impedes long-term international engagement. 


\title{
Stepping In and Out of the International Market: Internationalisation of Technology-Oriented Firms in Germany and the UK ${ }^{\S}$
}

\author{
by \\ Helmut Fryges*
}

July 2004

\begin{abstract}
For small high-tech firms international orientation is regarded as crucial for growth and long-term survival. Even newly founded technology based firms (NTBFs) are often internationally active shortly after their inception ("born globals"). However, in order to create jobs and have a sustainable influence on (macro)economic development, continuous growth of NTBFs is needed and research must focus on the continuous role of internationalisation. Based on longitudinal data, this paper examines empirically the long-term internationalisation behaviour of German and British technology-oriented firms founded between 1987 and 1996. Applying logit models, I am able to identify firm-specific success factors that influence the probability of entry into and exit from the international market. The results show, for instance, that firms can overcome high entry costs by acquiring firm-specific assets. Similarly, firm-specific resources prevent high-tech companies from exiting the international market. The strategic role of investment in R\&D is stressed in particular by the data.
\end{abstract}

Keywords: High technology industries, start-up, internationalisation.

JEL Classification: F23, L20, L60, L80

$\S$ I gratefully acknowledge financial support from the HSBC Innovation and Technology Group and the Anglo-German Foundation for the Study of Industrial Society. Helpful suggestions by Joachim Wagner, François Laisney, and Michael Woywode are also gratefully acknowledged. I thank Marc Rennert, Martin Becker, Natalie Gaier, Stefan Hoffmann, and Thea Platz for their competent research assistance and Tyler Schaffner for proof-reading. Special thanks go to Marc Cowling and Gordon Murray for carrying out the survey this study is based on in the UK. All remaining errors are my own.

* Centre for European Economic Research, Department of Industrial Economics and International Management, P.O. Box 103443, 68034 Mannheim, Germany, e-mail: fryges@zew.de 


\section{Introduction}

For small high-tech firms international orientation is regarded as crucial for growth and long-term survival. The 2002 Observatory of European SMEs (European Commission 2002) highlighted that in 1998/1999, 65 \% of all high-tech small and medium-sized enterprises (SMEs) from ten European countries were operating internationally and receiving $19 \%$ of their turnover from sales abroad. Since it is often argued that sales potential in European domestic markets is insufficient for the amortisation of high product research and development costs (see, e.g., McDougall et al. 1994, Bürgel et al. 2004), international business activities are expected to help European SMEs amortise $R \& D$ costs, thereby enabling them to fulfil the expectation related to them with respect to structural change, innovation, and job creation. Many empirical studies have examined the relationship between internationalisation and firm performance indicators like employment growth or labour productivity. However, only few of them (e.g., Girma et al. 2002) have found that internationalisation positively affects firm performance. Most other evidence (e.g., Clerides et al. 1998, Bernard and Jensen 1999, Arnold and Hussinger 2004) supports a reverse causation; namely that the positive correlation between international business activities and superior firm performance is due to self-selection of firms with better performance into the foreign market.

Within the larger group of high-tech SMEs, the interest of economists and politicians is focused in particular on newly founded, technology based firms (NTBFs). NTBFs constitute the smallest players in high-tech sectors so that the question arises, how they can cope with the challenges posed by high-tech markets. Entering the international market might be regarded as one of the greatest challenges faced by small and newly founded firms, but it is now established knowledge that NTBFs are often internationally active shortly after their inception (“infant multinationals”, Lindqvist 1991, “born globals”, McKinsey 1993a). Numerous studies have therefore investigated the internationalisation processes of NTBFs during their start-up period (e.g., Lindqvist 1991, McDougall et al. 1994, Bürgel et al. 2004). However, in order to create jobs and have a sustainable influence on (macro)economic development, continuous, long-term growth is needed and research must focus on the long-term development of NTBFs and the ongoing role of internationalisation. To the best of my knowledge, no other study has been performed that observes NTBFs over a relatively long time period, investigating long-term internationalisation behaviour. This paper will try to address this disparity. Based on longitudinal data, it examines empirically the long-term international business activities of young German and British technology-oriented firms. 
This paper's empirical research is based on two surveys that were conducted simultaneously in Germany and the UK. In 1997/1998, a joint research team comprised of analysts from the London Business School and the Centre for European Economic Research (ZEW) contacted a stratified random sample of German and UK-based NTBFs founded between 1987 and 1996 by sending out a written questionnaire (see Bürgel et al. 2004). It turned out that about two-thirds of the 600 responding firms were conducting international business activities at the time of the survey. In the summer of 2003, the ZEW and the University of Exeter contacted once again all surviving firms from the original sample (about $25 \%$ of the firms had already dissolved), which were then 12 years old on average. In order to ensure a high response rate, a computer-assisted telephone interview (CATI) was used. A response rate of $55 \%$ was obtained, and, after several consistency checks were performed, 217 companies were retained for the longitudinal analyses.

The focus of this paper is the long-term internationalisation behaviour of the firms surveyed. An advantage of our unique data set is that in contrast to most other studies, it contains a large set of explanatory, firm-specific variables (e.g., R\&D activities, product characteristics, and managerial profile) motivated by the literature of international management and observed over time. Thus, it is possible to identify "hard" success factors that are linked with long-term international business activities. The causality between internationalisation and firm performance is beyond the scope of this paper. However, understanding the way in which firm-specific characteristics affect firms' internationalisation behaviour could help future research explain the oft-observed positive correlation between performance and internationalisation.

Studying long-term internationalisation behaviour cannot be restricted to the analysis of foreign market entry. Although there is a high persistence in internationalisation behaviour, we observe market entry and exit in our data set: Just under $13 \%$ of firms that recorded international sales in 1997 had left the foreign market by 2003. This observation is in line with other empirical studies that have examined long-term international business activities (see, e.g., Roberts and Tybout 1997, Bernard and Jensen 2001). In order to analyse empirically entry into and exit from the foreign market, I apply logit models that firstly explain the transition from the internationalisation status "non-exporter" to that of "exporter”, i.e., foreign market entry; and secondly the transition from the internationalisation status "exporter" to that of "exporter", i.e. remaining internationally active. ${ }^{1}$ Of course, by trivial recoding, the second model explains exit from the foreign market.

1 In this paper, only firms that export their products or services are regarded as internationally active firms. This means that only internationalisation on the sales market is considered. Of course, firms may import investment 
The results show that there are minor differences between German and UK firms with respect to their internationalisation behaviour. Although the existence of sunk entry costs cannot be proved with our data set, the results are consistent with the sunk cost hypothesis. Firms can overcome high entry costs by acquiring firm-specific assets. Similarly, firm-specific resources prevent firms from exiting the foreign market. The strategic role of investment in R\&D is stressed particularly by the data. Moreover, employing internationally experienced managers constitutes an intangible asset that facilitates firms' export activities. If a firm’s products or services, however, require considerable individual client customisation, this presents a barrier to entry into the foreign market and impedes long-term international engagement.

The paper is organised as follows: Section 2 reviews the theoretical and empirical literature concerning firm internationalisation. Section 3 describes the data used for the empirical analysis and shows some descriptive statistics. The empirical methodology and the operationalisation of variables used in the empirical model are explained in section 4. The estimation results are presented and interpreted in section 5, and section 6 concludes.

\section{Theoretical Considerations and Literature Review}

As Bürgel et al. (2004) state, there is no single theoretical model that is able to explain the decision to internationalise of a firm that is both young and operates in a high-technology sector - such as those we observed. Therefore, we have to fall back on different models in order to motivate empirical analysis and derive hypotheses that can be tested. Theories that try to explain the internationalisation behaviour of individual firms can be categorized into models of economics and theories of international management. One basic approach in the field of economics is the model originally developed by Roberts and Tybout (1997), which was tested empirically by Roberts and Tybout themselves and by other authors in a series of papers². My theoretical considerations begin with a presentation of this model's core arguments.

Roberts and Tybout's model includes a vector of firm-specific variables that influence potential profit from international business activities and insofar determines a firm's decision whether to internationalise or not. However, mostly due to data restrictions, previous econometric studies

goods or components, i.e., internationalise on the procurement market. Although the latter way of internationalisation may also be important for small high-tech firms, it is neglected in this paper.

2 See, in particular, Bernard and Jensen (2001) and Bernard and Wagner (2001). 
have often contained only a relatively small number of observable firm characteristics. Since this study is based on survey data that were specifically collected to analyse the internationalisation behaviour of young and small high-technology firms (see section 3), I am able to use a larger set of firm-specific characteristics. In order to identify variables that can be expected to discriminate between exporters and non-exporters, I used internationalisation theories from the field of international management. In the following, I review the main arguments of three strands of theory: internationalisation process models (Johanson and Vahlne 1977, 1990), a theory of internationalisation from an entrepreneurial perspective (McDougall and Oviatt 2000; Andersson 2000), and the resource based view of a firm (e.g., Penrose 1959, Wernerfelt 1984).

The first model under theoretical consideration was originally formulated by Roberts and Tybout (1997) and applied, among others, by Bernard and Jensen (2001) and Bernard and Wagner (2001). ${ }^{3}$ It is based on the theoretical literature on sunk costs developed by Dixit (1989a, 1989b), Baldwin (1988), Baldwin and Krugman (1989), and Krugman (1989). Roberts and Tybout assume that, in period $t$, a rational firm $i$ maximizes the profits $\pi_{i t}$ it receives by selling the profitmaximizing level of exports $q_{i t}^{*}$ abroad. It is assumed that the firm is always able to produce the profit-maximizing level of exports $q_{i t}^{*}$. The firm's profit depends on factors exogenous to the firm $X_{i t}$, such as exchange rates, and firm-specific variables $Z_{i t}$, like firm size, age or product characteristics. Firm profit is given by

$$
\pi_{i t}\left(X_{i t}, Z_{i t}\right)=p_{t} q_{i t}^{*}-c_{i t}\left(X_{i t}, Z_{i t} \mid q_{i t}^{*}\right) .
$$

where $p_{t}$ is the price of goods sold abroad and $c_{i t}$ is the variable cost of producing quantity $q_{i t}^{*}$. As long as there are no entry costs, the firm will enter the foreign market in period $t$ if the period's profit is non-negative. The variable $Y_{i t}$ indicates the internationalisation status of firm $i$ in period $t$ and is defined as

$$
Y_{i t}=\left\{\begin{array}{ll}
1 & \text { if } \pi_{i t} \geq 0 \\
0 & \text { otherwise }
\end{array} .\right.
$$

Entering a foreign market, however, often causes costs, e.g., the costs of a marketing campaign or of setting up foreign sales channels, that may be regarded as sunk costs. Assuming that these sunk

3 Formulas and notation used in this paper are identical to those used by Bernard and Jensen (2001) and Bernard and Wagner (2001). 
costs $N$ must be fully paid in each period $t$ unless the firm had exports in the previous period $t-1$ (i.e. $Y_{i t-1}=1$ ), the one-period profit becomes

$$
\tilde{\pi}_{i t}\left(X_{i t}, Z_{i t}, Y_{i t-1}\right)=p_{t} q_{i t}^{*}-c_{i t}\left(X_{i t}, Z_{i t} \mid q_{i t}^{*}\right)-N \cdot\left(1-Y_{i t-1}\right) \cdot{ }^{4}
$$

In a dynamic framework the firm chooses a sequence of export levels $\left\{q_{i s}^{*}\right\}_{s=t}^{\infty}$ that maximizes expected current and discounted future profits

$$
\Pi_{i t}=E_{t}\left(\sum_{s=t}^{\infty} \delta^{s-t}\left[\tilde{\pi}_{i s} \cdot Y_{i s}\right]\right)
$$

where $\delta$ is the one-period discount rate.

The introduction of sunk costs induces an option value of waiting and leads to a spell of inaction, a phenomenon known as "hysteresis" (Dixit 1989a). In fact, the main interest of the Roberts and Tybout's study and the other papers cited above was to examine whether sunk costs are present and, if this is the case, to quantify their effects on the decision to enter and exit the foreign market. If sunk costs are relevant, firms may continue to export even if foreign sales are no longer profitable in the current period in order to avoid re-entry costs. According to this theory, a transitory depreciation of the respective domestic currency will cause a permanent (or at least long-term) increase in the number of firms involved in the international market, even if the domestic currency subsequently re-appreciates.

To measure the effect of sunk costs on the decision to internationalise, Roberts and Tybout estimate a binary-choice non-structural model of the form

$$
Y_{i t}=\left\{\begin{array}{cc}
1 & \text { if } \beta X_{i t}+\gamma Z_{i t}-N \cdot\left(1-Y_{i t-1}\right)+\varepsilon_{i t} \geq 0 \\
0 & \text { otherwise }
\end{array} .\right.
$$

In order to consider unobserved firm-specific heterogeneity, the error term $\varepsilon_{i t}$ is assumed to consist of a permanent firm-specific element $\kappa_{i}$ and a transitory component $\eta_{i t}$. The latter term follows a first-order autoregressive process, $\eta_{i t}=\rho \eta_{i t-1}+v_{i t}$, so that

$$
\varepsilon_{i t}=\kappa_{i}+\eta_{i t} .
$$

4 This is the simplest way of introducing sunk costs. Alternatively, it can be assumed that current profits are also affected by the status of internationalisation from periods prior to the immediately preceding interval (cf. Roberts and Tybout 1997), or we can introduce exit costs from the foreign market. The basic argumentation, however, remains unchanged. 
Using a data set of Colombian plants in the manufacturing sector observed between 1981 and 1989, inclusive, Roberts and Tybout estimated a random effects probit model and discovered that sunk costs are relevant. If a firm exported in the previous year (i.e. $Y_{i t-1}=1$ ), the probability of it being international in the current period would increase by $63 \%$. However, the effect of previous international activities has been shown to depreciate rapidly: After a two-year absence from the foreign market, re-entry costs are no longer different from the costs faced by firms entering the international market for the first time. Apart from the effect of sunk costs, Roberts and Tybout confirmed that observed and unobserved plant characteristics have a significant influence on the firms' export behaviour. The probability to internationalise increases with firm size, age, and a dummy variable that indicates whether the plant is owned by a corporation.

Bernard and Jensen (2001) used data collected on U.S. manufacturing plants between 1984 anad 1992 to estimate the same model as Roberts and Tybout. They confirmed the relevance of both sunk costs and plant-specific variables in the plants' export behaviour. Applying a random effects probit model, the probability of a plant exporting at a certain year increases by $62 \%$ if the plant exported in the previous year. The measure of the effect of the lagged export status, however, depends on the econometric method applied. Using a linear probability model with fixed effects, the marginal effect of the lagged internationalisation status drops substantially to $20 \% .56$

Beside Roberts and Tybout's model, there are only a few approaches in the economics literature to modelling the internationalisation behaviour of individual firms. One alternative approach has been developed by Lautanen (2000). He interprets entry into a foreign market as an innovation adopted by a firm. At least for small firms, Lautanen argues, it is possible to draw analogies between the adoption process of a new technology and exporting: Both processes are associated with uncertainty, they involve learning behaviour, and they are (or can be) both initiated through personal contact-related stimuli. Lautanen's two-period model, therefore, consists of two parts: In the first part, the diffusion of information on international business activities is modelled as an epi-

5 Bernard and Jensen (2001) provide a detailed discussion of the role of different econometric methods when estimating the binary choice framework given in equation (5). They stress that the fixed effects estimator in a linear probability model is almost surely biased downward but gives a lower bound of the effect of previous export status.

6 Using data of German manufacturing firms in Lower Saxony, Bernard and Wagner (2001) get similar results for the effect of sunk costs. The lagged export status increases the probability of exporting today by 38 \% (linear probability fixed effects model), or $68 \%$ (random effects probit model) respectively. 
demic learning process similar to technology diffusion. ${ }^{7}$ The diffusion of information determines which firms become interested in exporting in each period. The second part explains which firms finally commit to exporting, conditional on becoming interested in exporting in the first stage of the model. The decision on committing to exporting is determined by three conditions: First, a profitability condition states that a firm will only export if it receives non-negative (expected) profits from its export activities. As in Roberts and Tybout, the profitability condition depends on a set of firm-specific variables. Second, a firm will only commit to exporting in the first period if it is not profitable to wait until the second period of the model before entering the foreign market (arbitrage condition). Finally, the third condition demands that the firm has enough resources for its planned export activities (feasibility condition).

Since the data set used for this paper's empirical analysis does not contain information on the stimulus that leads to international business activities, the first part of Lautanen's model cannot be tested empirically. However, the second part of the model shows some parallels to the model of Roberts and Tybout. In both models, firms will enter the foreign market if a profitability condition is met. The models contain an option of waiting, whereas, in contrast to the model of Lautanen, the Roberts and Tybout's model explicitly traces a possible delay of entry (and exit) back to the existence of sunk costs. Finally, firms' internationalisation behaviour in both theories depends on the availability of firm-specific resources. Hence empirically analysing firm-specific variables that determine the export activities of high-tech firms, as it is the purpose of this paper, is consistent with both models.

In order to identify variables that can be expected to discriminate between exporters and nonexporters, it is helpful to fall back on theories of internationalisation from the field of international management. One of the most influential theories is the internationalisation process model developed by Johanson and Vahlne $(1977,1990)$. They regard internationalisation as a gradual process in which firms incrementally increase their commitment in foreign markets. A commitment is always associated with uncertainty. The firm extends its international business activities until its particular maximum tolerable risk is reached. This is a function of the degree of the firm's risk aversion and the firm's resource position. The commitment of resources to a foreign market increases knowledge of that market and thus reduces any existing uncertainty about the foreign environment. The internationalisation process is therefore combined with a dynamic learning

7 Models of technology diffusion, among them epidemic learning models, rank, stock, and order effect models are described in detail in Stoneman (1983) and Karshenas and Stoneman (1993). 
process over time. An initial involvement in a foreign market reduces uncertainty, which in turn induces an additional commitment to this market. As a consequence, firms start their international activities with relatively few resources because the commitment of these resources is associated with a relatively high amount of risk. Improved knowledge acquired over time through additional commitment to the market leads to more resource-intensive international activities, since the latter become associated with less risk than the firm's initial foreign activities.

The internationalisation process model is the basis of the so-called "stage" models of internationalisation (e.g., Bilkey and Tesar 1977, Bilkey 1978). In these theories the internationalisation behaviour of a firm is linked with different stages of the firm's life cycle, starting from no foreign sales and expanding its international activities incrementally to a more resource-intensive commitment to foreign markets until a final stage of foreign direct investment is reached. Hence, the stage models not only try to explain the entry into a foreign market per se, but also the choice of the optimal market entry mode used at different stages of the firm's international involvement.

The most important criticism of the internationalisation process model and especially of stage theories is the quasi-deterministic character of the models (Reid 1983). The argument is that firms can and will decide on an optimal entry mode and on expansion of their international activities contingent on market conditions. There is no need to proceed in the incremental way described by the model. Johanson and Vahlne have themselves already listed three exceptions where firms are likely to deviate from the gradually expanding commitment predicted by their model. Firstly, large firms may have enough resources to take larger steps in their internationalisation process. Secondly, relevant knowledge that reduces uncertainty about a foreign market can be acquired by other means than own experience, for example by employing an internationally experienced manager. Finally, if market conditions in different foreign markets are homogenous, firms may generalize experience gained in one market to make larger internationalisation steps in another.

The criticism of the process model's quasi-deterministic character has more recently led to theories that combine the research paths of international business and entrepreneurship. McDougall and Oviatt (2000, p. 903) define international entrepreneurship as "a combination of innovative, proactive, and risk-seeking behaviour that crosses national borders and is intended to create value in organisations". The key idea of international entrepreneurship is that the availability of resources is not enough to initiate an internationalisation process (Andersson 2000). An acting entrepreneur is needed to trigger the internationalisation process. Entrepreneurs make strategic choices that determine the optimal way of internationalisation conditional on their firm's resources and their own capabilities and preferences. The entrepreneurial perspective, however, is not restricted to 
individuals or even firm founders. Entrepreneurial behaviour in large companies, often called “intrapreneurship”, is also covered by this concept.

The inclusion of entrepreneurship research allows us to trace different patterns of the internationalisation process of firms back to characteristics of the entrepreneurs. Based on a case study analysis of Swedish firms, Andersson (2000) identified three different types of entrepreneurs. The technical entrepreneur is mainly interested in technology and the development of the production process. In this case, an unsolicited order from abroad may lead to exports (“pull strategy”). On the contrary, the marketing entrepreneur proactively creates the internationalisation process of his firm ("push strategy"). He creates new channels to reach foreign customers and is willing to invest a relatively large amount of resources in order to penetrate the foreign market quickly. The third type of entrepreneurs Andersson calls “structural” entrepreneurs. This concept is relevant for large companies and mature industries, and thus less important for the sample of NTBFs examined by this paper. Structural entrepreneurs regard internationalisation as but one part of their overall strategy. They organize and restructure (large) firms and, in this context, create an international business strategy, e.g., by choosing mergers and acquisitions as a method of entry.

The concept of international entrepreneurship as well as the model of Johanson and Vahlne emphasize the role of intangible resources like experience or entrepreneurial capabilities in the internationalisation process. This is also a main topic when discussing the resource-based view (RBV) of a firm (e.g., Penrose 1959, Wernerfelt 1984) and the more recent theories that regard organisational capabilities of firms as determinants of their outcome (e.g., Teece et al. 1997, Madhok 1997). RBV models analyse how resources are accumulated and deployed by firms. A firm is interpreted as an idiosyncratic bundle of assets (physical resources as well as intangible resources like know-how, experience or tacit knowledge). Since physical assets are relatively easily obtained or imitated, a firm differentiates itself from its rivals by the intangible resources it possesses. These determine how efficient physical assets can be used, and are therefore vital to the firm's performance. With respect to the internationalisation process, this means that the costs of market entry can be reduced if intangible resources lead to a more efficient use of the firm's physical resources.

Although RBV models offer a valuable perspective on how intangible and physical resources interact, the theory remains vague in many respects. For example, it does not derive hypotheses about causalities between specific assets and firm performance. In our context, RBV models explain neither the timing of entry into a foreign market nor the entry mode used by the firm. Nevertheless, RBV models can help us deal with the peculiarities of the internationalisation process of firms that are small, young, and belong to a high-tech sector. A resource-based perspective 
seems to be particularly relevant for samples of NTBFs similar to the one chosen for this study. Indeed, general variables like size and age probably cannot discriminate between exporters and non-exporters since, nearly all selected firms are of similar age and size. 89

\section{Data and Descriptive Analysis}

This paper is intended to examine the internationalisation behaviour of technology-oriented firms in Germany and the UK. In order to identify these firms, the definition of high-technology manufacturing sectors in the UK established by Butchart (1987) was used. Butchart provides a definition based on, firstly, the ratio of R\&D expenditures to sales and, secondly, the share of employees working in R\&D. A sector is defined as "high-tech" if it is characterised by a "substantial aboveaverage" value in at least one of the two criteria and an "above-average" value in the other. Using this definition, Butchart identified nineteen UK 1987 SIC codes, which were translated into the NACE Rev. 1 code and are listed in detail in Table 5 of this paper's appendix. Table 5 defines four aggregated manufacturing sectors and augments Butchart's list with a number of selected service sectors (cf. Bürgel et al. 2004).

The data for this paper's empirical analysis result from two surveys simultaneously carried out in Germany and the UK. The source data set originates from Dun \& Bradstreet in the UK and Creditreform ${ }^{10}$ in Germany. Using these databases, all firms with at least three employees in 1997 that are operating in one or more high-tech sectors as defined by Butchart (1987) and had been founded as legally independent companies ${ }^{11}$ between 1987 and 1996 were selected. This resulted in a population of 3,562 firms from the UK and 5,045 from Germany. The sample composition of the 1997 population is given in Table 6 in the appendix. A random sample of 2,000 firms for each

8 Oviatt and McDougall (1994), for example, regard new technology-based firms that internationalise quickly as firms with an intangible, knowledge-based competitive advantage. This perspective is consistent with the resource based view of the firm.

9 The reasoning of RBV models that firm-specific assets determine the internationalisation behaviour of firms is similar to the role of ownership advantages in Dunning's OLI (ownership, location, internalisation) framework, also called the "eclectic paradigm" (Dunning 1993). According to Dunning himself, the eclectic paradigm intends to explain "what are" rather than, in the normative sense, "what should be" a firm's international business activities.

10 As Germany's largest credit rating agency, Creditreform has the most comprehensive database of German firms at its disposal. Creditreform provides data on German firms to the Centre for European Economic Research (ZEW) for research purposes.

11 Subsidiaries, de-mergers or firms that were founded as a management buy-out (MBO) or buy-in (MBI) were excluded from the analysis. 
country was drawn from the population, stratified by size, sector (manufacturing versus services), and, for Germany, by region (West and East Germany).

The firms were first contacted in winter 1997/1998 by sending out a written questionnaire. The first survey was carried out by the London Business School in the UK and the Centre for European Economic Research (ZEW) in Germany. The written questionnaire contained questions regarding the profile of the firms' founder(s), product characteristics, international business activities, entry modes into foreign markets, and perceived opportunities and risks of international activities. 362 completed questionnaires returned from the UK, 232 questionnaires from Germany, which resulted in a combined net sample of nearly 600 NTBFs from the two countries. The net sample showed no bias with respect to age, size, or sector when compared with the random sample. A bias with respect to internationalisation behaviour could, however, not be ruled out. ${ }^{12}$

In order to determine the development and status of internationalisation of this sample of 600 NTBFs, a joint research team from the University of Exeter and the ZEW prepared a new survey in which all former responding firms were to be contacted a second time. In 2003, the companies from the original sample were on average of 12 years old. Thus, part of our firms were no longer definable as new technology-based firms. ${ }^{13}$ Considering this notion, we shifted our interest from analysing newly founded firms to a more longitudinal perspective of firm development.

To determine the target sample of the second survey, at first all formerly responding firms that turned out to be mismatches (e.g., non-high-tech firms, non-independent foundations) were excluded. We then eliminated each German firm labelled in the database of Creditreform as “dead" (due to bankruptcy as well as voluntary firm closure) at the beginning of $2003 .{ }^{14}$ In the UK, firms that could be identified as dead by the researchers themselves were also excluded from the target sample. ${ }^{15}$ As a result, we got a final target sample of 188 German and 250 UK-based, formerly responding firms that were contacted.

12 The first survey is described in detail in Bürgel et al. (2004). This report also includes numerous descriptive and econometric analyses of this unique data set.

13 In his influential study, Little (1977) used a definition of NTBFs which includes firms as old as 25 years. In contrast, the first survey this paper is based on considered only firms that were ten years of age or younger at the time it was taken, which is in line with more recent studies of NTBFs (see, e.g., Storey and Tether 1996).

14 According to the analysis of Prantl (2001), those firms indicated as “dead” by Creditreform have almost certainly left the market. The reverse, however, is not true: Voluntary firm closures are often recorded by Creditreform after considerable delay, causing the number of closed firms to be underestimated.

15 Table 6 in the appendix also shows the number of still-living firms in 2003. Since the number of mismatches in the population is indeterminable, possible mismatches are not considered in Table 6. 
The second survey was conducted in 2003 via computer-aided telephone interviews (CATI). The research team decided on a telephone survey because, due to the limited number of formerly responding firms in the target sample, the assurance of a relatively high response rate and thereby a sufficiently high number of observations was necessary to obtaining reliable econometric results. Fortunately, in both the UK and Germany, the response rate exceeded $50 \%$, giving us a pool of 244 completed interviews. After performing several consistency checks, 217 companies were retained in the data set for econometric analyses.

On average, 26 employees worked in the sampled firms in 2003. Considering only those firms that participated in both surveys, the average number of employees had increased by an average of 7 employees (or $37 \%$ ) since 1997. Table 1 compares the mean number of employees in firms with and without international business activities. The 1997 and 2003 survey both reveal a higher mean value (and a higher median, not shown here) of number of employees for firms with exports compared with non-exporting firms. Applying a t-test proves that total employment of exporting firms significantly exceeds that of firms with only domestic sales in both Germany and the UK. Regarding firm age (measured in years), the firms in our sample were an average of 12 years old in 2003. The mean of firm age is always higher for exporting firms. However, based on a t-test the differences are not significant.

Table 1: Comparison of Means between Exporters and Non-Exporters

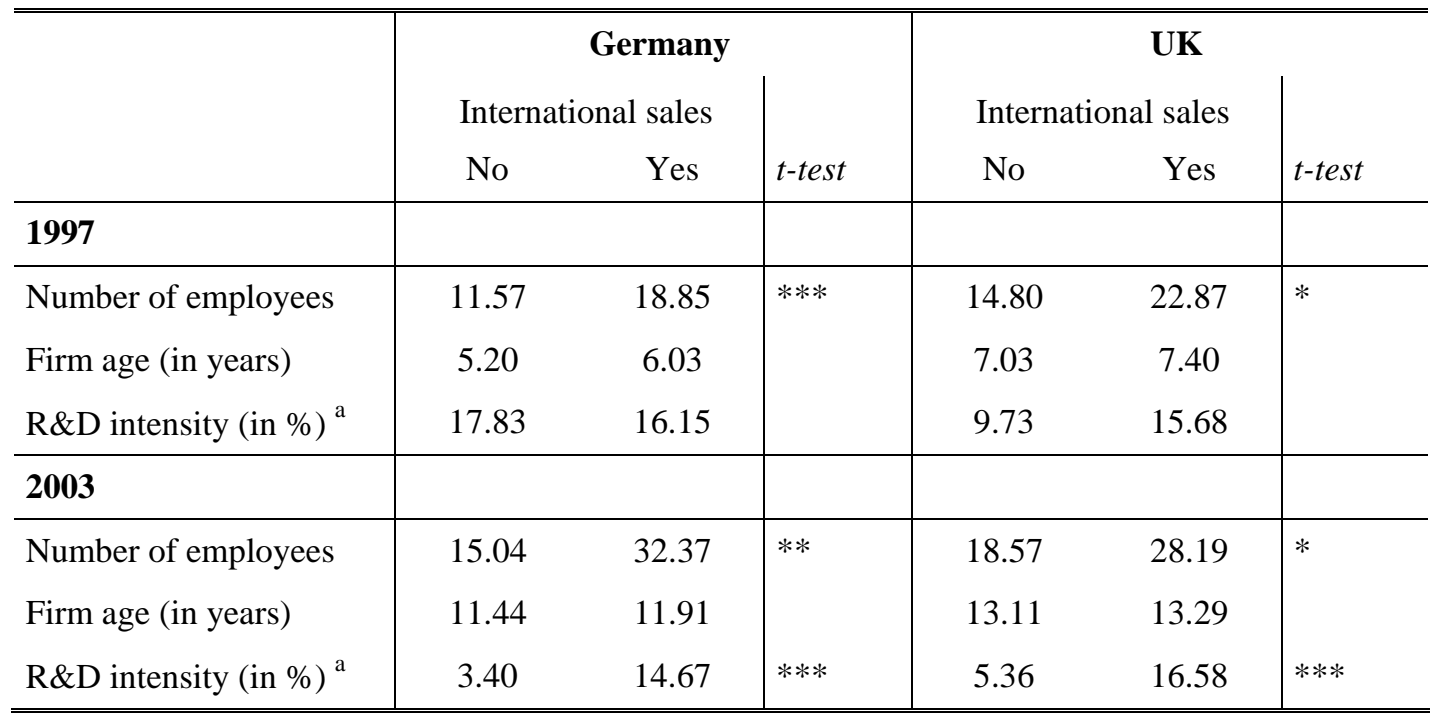

a expenditures on R\&D as percentage of sales.

* $10 \%$ level of significance; ** $5 \%$ level of significance; *** $1 \%$ level of significance.

Remark: Only firms that participated in both surveys have been considered.

Source: ZEW, University of Exeter, own calculations. 
In 1997, German and UK-based technology-oriented firms spent an average of $15.4 \%$ of their total sales on research and development. Neither in Germany nor in the UK is the mean of R\&D intensity of exporting firms significantly different from the respective value of non-exporting firms, although it should be noted that for the UK this is the result of a high standard error. In 2003, R\&D intensity decreased by two and a half percentage points to an average of $12.8 \%$. This is not necessarily a result of falling expenditures on R\&D; It may also be attributed to rising sales. During the early stage period covered by the 1997 survey, many high-tech firms incur high costs developing new products or services that can be commercialized. On the other hand, total sales might be relatively modest until the firm becomes established in the market. Therefore, $R \& D$ intensity can be expected to be higher during an early stage of a high-tech firm's life cycle than in a later stage, making the declining mean R\&D intensity between 1997 and 2003 less surprising. It is, however, remarkable that the drop in R\&D intensity has been caused mainly by non-exporting firms, whereas the average R\&D intensity of exporters has changed only slightly. As a consequence in 2003, the mean R\&D intensity of firms with international sales is significantly higher than the mean of non-exporting firms. In fact, among those firms that have never had international sales (see Table 3 and the explanations below) three-quarters did not carry out any own R\&D activities in 2003.

Table 2 shows the share of firms with and without international sales in 1997 and 2003, respectively, again considering only those firms that participated in both surveys. In both countries, more than two-thirds of responding firms had international sales. Even the majority of firms from the service sector (mainly software firms) turned out to have international business activities, although the percentage of firms with foreign sales is smaller than in any aggregated high-tech manufacturing sector. In the manufacturing industry, firms that belong to the sectors ICT-hardware, engineering, and health/life sciences export more often than other manufacturing firms. In the UK-based sample, all firms in the sectors ICT-hardware and health/life sciences even had international business activities. However, it should be mentioned that the number of observations in these two sectors is rather small. In Germany, only 5 ICT-hardware firms (15 firms in health/life sciences) answered both surveys; in the UK 12 ICT-hardware firms (10 in health/life sciences). ${ }^{16}$

16 In fact, in contrast to the first survey where no sector bias was found, the ICT-hardware sector is underrepresented in the German as well as in the UK-based sample. Conversely, the health/life sciences sector (engineering sector) is overrepresented in the German (UK-based) sample. 
Table 2: Firms with International Sales, by High-tech Sector (in \%)

\begin{tabular}{l|cc|cc|cc|cc}
\hline \multirow{2}{*}{ Sector } & \multicolumn{4}{|c|}{ Germany } & \multicolumn{4}{c}{ UK } \\
& \multicolumn{2}{|c|}{1997} & \multicolumn{2}{c}{2003} & \multicolumn{2}{c}{1997} & \multicolumn{2}{c}{2003} \\
\hline Software/services & No & Yes & No & Yes & No & Yes & No & Yes \\
ICT-Hardware & 50.0 & 50.0 & 45.5 & 54.5 & 40.6 & 59.4 & 35.5 & 64.5 \\
Engineering & 20.0 & 80.0 & 20.0 & 80.0 & 0.0 & 100 & 0.0 & 100 \\
Health/life sciences & 15.8 & 84.2 & 10.5 & 89.5 & 20.0 & 80.0 & 13.8 & 86.2 \\
Other high-tech manuf. & 20.0 & 80.0 & 20.0 & 80.0 & 0.0 & 100 & 0.0 & 100 \\
\hline Total & 27.3 & 72.7 & 27.3 & 72.7 & 25.7 & 74.3 & 31.4 & 68.6 \\
\hline \hline
\end{tabular}

Remark: Only firms that participated in both surveys have been considered.

Source: ZEW, University of Exeter, own calculations.

When calculating the percentages of firms with foreign sales for the complete cross section of the 1997 survey, the percentages turn out to be generally smaller compared with the respective values of the firms that participated in both surveys, those considered in Table 2. There are two possible selection processes that can lead to this result. Firstly, firms that answered the second survey may have behaved differently compared with the complete target sample from the 2003 survey. Since we did not carry out a non-response analysis, we do not know whether there are differences between respondents and non-respondents in 2003, but the relatively high response rate is an indication that this interpretation is not very likely. Secondly, the firms still currently living may have behaved differently in 1997 compared with the period's general cross section, i.e., including those firms that had already dissolved between the two surveys. The higher percentage of internationally active firms in 1997 among those that survived the following six years may serve as an indication of a positive correlation between internationalisation and performance; This needs further research but is beyond the scope of this paper. ${ }^{17}$

As Table 2 further shows, there was a slight increase in the firms' international engagement between 1997 and 2003 in all sectors, with the exception of other manufacturing firms in the UK. Apart from this sector, the share of firms with exports in 2003 was at least as high as in 1997. These numbers, however, do not allow us to see how many firms had entered the foreign market for the first time since 1997 and how many firms had left the market. Roberts and Tybout (1997) have already shown that, although there is a high persistence in the individual firm's status of internationalisation due to sunk costs, quite a high number of firms changes internationalisation

17 The effect of internationalisation on firm survival has been examined, for example, by Bernard and Jensen (1999). 
status, leading to entry and exit over time. The development of internationalisation status of the sampled firms is listed in Table 3. This table also includes a separate column for the time of startup. A firm is defined to have international sales during its start-up period if it entered its first foreign market no later than one year after firm formation. These firms are called "infant multinationals” (Lindqvist 1991) or "born globals” (McKinsey 1993a).

Table 3: Development of Internationalisation Status

\begin{tabular}{ccc|c|c|c|c}
\hline \hline \multicolumn{3}{c|}{ Foreign sales (yes=1) } & \multicolumn{3}{c}{ Germany } & \multicolumn{2}{c}{ UK } \\
Start-up & 1997 & 2003 & $\%$ & $n$ & $\%$ & $n$ \\
\hline 1 & 1 & 1 & 27.6 & 26 & 25.0 & 29 \\
1 & 1 & 0 & 3.2 & 3 & 0.9 & 1 \\
1 & 0 & 1 & 0.0 & 0 & 0.9 & 1 \\
0 & 1 & 1 & 30.9 & 29 & 45.7 & 53 \\
1 & 0 & 0 & 0.0 & 0 & 0.0 & 0 \\
0 & 1 & 0 & 8.5 & 8 & 6.9 & 8 \\
0 & 0 & 1 & 13.8 & 13 & 6.9 & 8 \\
0 & 0 & 0 & 16.0 & 15 & 13.8 & 16 \\
\hline \hline
\end{tabular}

Source: ZEW, University of Exeter, own calculations.

About a quarter of all firms had international sales shortly after their formation. Further, just under $31 \%$ of the German firms and $46 \%$ of the firms in the UK did not export during their start-up period, but were internationally active when the two surveys were conducted. On the other hand, $16 \%$ of German and almost $14 \%$ of UK firms never had any international sales. More interesting for the purpose of this paper are the firms that have changed their status of internationalisation. Ignoring for the moment the firms' behaviour at time of start-up, nearly $12 \%$ of German and $8 \%$ of UK-based firms left the international market between 1997 and 2003. During the same period, $14 \%$ of German firms and $8 \%$ of firms sited in the UK entered the international market. Thus, German high-tech firms more frequently change their status of internationalisation, whereas UK firms show a higher persistence in their internationalisation behaviour.

The analysis of the development of the internationalisation status in this paper has, however, one shortcoming: We can only determine the status in the years 1997 and 2003 alone. We do not know whether firms had foreign sales in each year or whether they left the foreign market for a couple of years and re-entered just before the second survey was conducted. In other words, we do not have annual information on the firms' export status trajectories. 


\section{Econometric Implementation}

This paper concentrates on entry into and exit from the international market. Since the firms have been observed only twice, dynamic probit models, as they were used by Roberts and Tybout (1997) or Bernard and Jensen (2001) (see section 2), are not suitable for our data set; Strong restrictions would have to be imposed to identify the model (cf. Honoré and Kyriazidou 2000). Instead, I estimate the probability of a transition from one status of internationalisation to another or the same status in the next period. I apply a model inspired by Gouriéroux (2000) and used by Van Phu et al. (2000) in order to estimate the transitions between different states of firm performance.

As before, let $Y_{i t}$ denote the status of internationalisation $j$ in which firm $i$ is in time $t$, with $Y_{i t}=1$ if firm $i$ exports in time $t$ and $Y_{i t}=0$ otherwise. The transition probabilities are modelled with the logistic formulation and depend on a set of explanatory variables. The probability of transition of firm $i$ from status $j$ in $t-1$ to status $j^{\prime}$ at time $t$ is then given by

$$
P_{i j j^{\prime}}(t) \equiv P\left(Y_{i t}=j^{\prime} \mid Y_{i t-1}=j\right)=\frac{\exp \left(x_{i t} \beta_{i j^{\prime}}\right)}{\sum_{j^{\prime}=0}^{1} \exp \left(x_{i t} \beta_{j j^{\prime}}\right)},
$$

$i=1, \ldots, N, t=0,1,2$, and $j, j^{\prime}=0,1$.

Imposing the identifying restriction $\beta_{j 0}=0$, we obtain

$$
\begin{aligned}
& P_{i j 0}(t)=\frac{1}{1+\exp \left(x_{i t} \beta_{j 1}\right)}, \\
& P_{i j 1}(t)=\frac{\exp \left(x_{i t} \beta_{j 1}\right)}{1+\exp \left(x_{i t} \beta_{j 1}\right)},
\end{aligned}
$$

with $j=0,1$. Thus, a logit model is specified for each row of the transition matrix. Let us define $n_{i, t-1, t}\left(j j^{\prime}\right)=1$ if firm $i$ occupies status $j$ in $t-1$ and status $j$ ' at time $t$, and 0 otherwise. Then the loglikelihood conditional on the status occupied at time $t-1$ is

$$
\ln L=\sum_{j=0}^{1} \sum_{j^{\prime}=0}^{1} \ln L_{i j^{\prime}} \text {, with } \ln L_{i j^{\prime}}=\sum_{i=1}^{N} \sum_{t=1}^{2} n_{i, t-1, t}\left(j j^{\prime}\right) \ln P_{i j j^{\prime}}(t) \text {. }
$$


Since the quantity $\sum_{j^{\prime}=0}^{1} \ln L_{j j^{\prime}}$ only depends on $\beta_{j 1}$, the maximum likelihood estimators $\hat{\beta}_{j 1}$ can be obtained by individually maximizing the elements of $\sum_{j^{\prime}=0}^{1} \ln L_{j j^{\prime}}, j=0,1 .{ }^{18} 19$

In order to discriminate between firms that have entered the international market and firms that stay absent from it, I estimate a conventional logit model. Regarding the second element of the log-likelihood function, where I distinguish between firms that continued to have international sales and firms that left the international market between the two observed points in time, the problem emerges that an exit from the foreign market is rare compared with the event of staying internationally active. Based on McCullagh and Nelder (1989), King and Zeng (2001) show that in rare events data in finite samples, the maximum likelihood estimator $\hat{\beta}$ is biased and that the bias is amplified the smaller the proportion of the rare event. Moreover, the estimated probability of the rare event - in our case, the estimated probability of exit from the foreign market $\hat{P}_{i 10}$ - is too small, and hence the probability of the more frequent event, i.e., the probability of staying in the international market $\hat{P}_{i 11}$, is overestimated.

King and Zeng (2001) show that the bias of $\hat{\beta}$ can be calculated applying a weighted least-squares estimation, thereby leading to a bias-corrected estimate of $\beta$, denoted $\tilde{\beta}$. Furthermore, King and Zeng derive an analytical approximation for estimating the probability $P_{i 11}$ as

$$
P_{i 11} \approx \frac{1}{1+\exp \left(x_{i} \tilde{\beta}_{11}\right)}+C_{i}=\tilde{P}_{i 11}+C_{i},
$$

18 It is important to note that the dependent variable is the transition probability and not the individual firm. Provided that there are no missing values for the independent variables, a single firm will enter the log-likelihood function twice: with the transition probability from the start-up period to 1997 and with the transition from 1997 to 2003.

19 I have also extended this model by allowing for the possibility of random effects, one for each firm and for each type of transition as proposed by Van Phu et al. (2000). The linear index the transition probabilities depend on now becomes $x_{i t} \beta_{j j^{\prime}}+\sigma_{j j} u_{i j j^{\prime}}$. The terms $\sigma_{j j} u_{i j j^{\prime}}$ are assumed to be mutually independent and independent of $x$, with mean 0 and variance $\sigma_{j j}^{2}$. The random variable $u_{i j j^{\prime}}$ has been assumed to be standard normal distributed. The parameters $\sigma_{j j}$, have to be estimated. This model has been estimated by simulated maximum likelihood. However, a likelihood ratio test of the restricted model (i.e. with all $\sigma_{j j}$, set to 0 ) against the unrestricted model cannot reject the Null hypothesis $\left(\operatorname{LR} \chi^{2}(4)=5.702\right.$; [Prob $>\chi^{2}$ ] = 0.223). Apparently, the large set of firm-specific variables in my estimation equation (see below) is able to discriminate between exporters and non-exporters, i.e., a large part of firm-specific heterogeneity is, in fact, observed. Therefore, in the following I will restrict my analysis to a model without simulated heterogeneity. 
where the correction factor is

$$
C_{i}=\left(0.5-\tilde{P}_{i 11}\right) \tilde{P}_{i 11}\left(1-\tilde{P}_{i 11}\right) x_{i} \operatorname{Var}\left(\tilde{\beta}_{11}\right) x_{i}^{\prime} \cdot{ }^{20}
$$

The estimator $\tilde{P}_{i 11}+C_{i}$, which is called an approximate Bayesian estimator, is not unbiased but it is superior in the sense that it has a smaller mean square error than other estimators of $P_{i 11}$ (see King and Zeng 2001). Therefore, I use this rare event logit model to estimate the second element of the log-likelihood function in equation (10).

The vector of explanatory variables $x_{i t}$ may contain both firm-specific variables, denoted $Z_{i t}$ in equation (5), and variables exogenous to the firm, denoted $X_{i t}$. According to the trade theories the dynamic model of Roberts and Tybout (1997) is based on (cf. Baldwin and Krugman 1989, Krugman 1989), exchange rates are supposed to play a crucial role in influencing a firm's decision to export. To determine the effect of an exchange rate movement, I constructed weighted real exchange rate indices for the euro (Deutsche Mark) and the British pound for each of the five hightech sectors defined in Table $5 .{ }^{21}$ The weights are defined by the share of exports of each respective industry to that industry's ten most important export countries as revealed by the 1997 survey, computed separately for German and UK firms. Calculating exchange rate indices in this way, we are essentially able to estimate the reaction of (potential) exporters to changes in prices on the industry's most important foreign markets (cf. Bernard and Jensen 2001). However, since the firms in the sample are observed only twice, the weighted exchange rate indices take only two different values for each industry in Germany and the UK, respectively. Moreover, the calculated indices show only minor movements in the weighted real exchange rates of the euro (Deutsche Mark) and the pound from 1997 to $2003 .{ }^{22}$ As a consequence, in a logit regression the variable "industry real exchange rate" interacts with the integer. In fact, including the index in a regression with an integer leads to a numerically high point estimator of the integer, which is nevertheless not significant due to a very high standard error. For this reason, I decided to estimate the logit model without an integer but including the real exchange rate.

20 For simplicity, I have neglected the time subscript $t$ in this formula.

21 Nominal exchange rates were taken from the historical exchange rate database of Oanda Corp., available at http://www.oanda.com. Consumer price indices used to calculate real exchange rates were taken from Global Economic Data of EconStats, available at http://www.econstats.com.

22 The nominal exchange rate of the euro and the pound to the most important foreign currency, the US dollar, indeed changed significantly during the period from 1997 to 2003. But in 1997, the average rate was nearly the same as the average rate in 2003. 
Firm-specific variables can be derived from the literature of international management. Four dimensions of firm characteristics will be considered: firm size and age, R\&D activities, product characteristics, and human capital and management capabilities.

Firm size and age are important elements of the internationalisation process model and of the stage models. If a firm increases its international activities gradually as predicted by the stage models of internationalisation, it will start with no international activities and will enter its first (unknown) foreign market at a later stage of its life cycle. Therefore, we hypothesise that firm age, measured by the logarithm of firm age at time of the respective survey, is positively correlated with an arrival status (status $j$ ' at time $t$ in equation (10)) “exporter”. Similarly, Johanson and Vahlne (1990) state that larger firms posses more resources and are more likely to take larger internationalisation steps - independent of their age. Thus, we can expect that firm size, measured by the logarithm of a firm's number of employees at time of the respective survey, increases the probability of remaining an exporter or of changing internationalisation status to become an exporter at time $t$.

Resource-based theories emphasise that firms discriminate from their rivals by intangible resources. One way to gain such firm-specific assets that are only imperfectly imitable by other firms is by conducting R\&D activities and developing novel technology to produce the firm's product (cf. Bürgel et al. 2004). Firms’ R\&D activities are measured by the percentage of total sales spent on R\&D. A higher R\&D intensity should lead to a higher propensity of being engaged in international markets. Further, firms were asked to describe the innovativeness of their best selling product or service by indicating the technology incorporated in the firm's product. In the econometric analysis, a dummy variable will be included taking the value 1 if, according to the representatives of the firm, the technology used by the firm can best be described as "tried and tested technology". We suppose that the use of "tried and tested technology" negatively affects firms' inclination to export to a foreign market, since such technology can easily be imitated by rival companies.

Product characteristics may influence the internationalisation behaviour of firms. High customisation requirements may act as a constraint to entering the foreign market: They involve close contacts to end-users, which induce high transaction costs prior to selling the product. Similarly, regular maintenance and the necessity of frequent upgrades lead to high transaction costs after the product has been sold (cf. Williamson 1985 for a presentation of transaction cost economics). The questionnaires used in both surveys measure the degree of customisation and necessary maintenance on a five point Likert scale ranging from 1 "unimportant" to 5 "very important". For the 
econometric estimations, two dummy variables are used taking the value 1 , if the firm has classified the requirements of customisation and maintenance, respectively, as "important" (4) or "very important” (5). Moreover, a dummy variable indicating whether the firm's best selling product is sold to end-users is included. This variable is also presumed to reduce the probability of beginning or continuing to export due to the higher communication and distribution costs involved in selling a product to end-users.

Human capital and the capabilities of the management team are highlighted by the theories of international management presented in section 2. As an exclusion of the internationalisation process model, Johanson and Vahlne (1990) mentioned the possibility that the knowledge necessary to reducing uncertainty about a foreign market can be acquired by employing an internationally experienced manager. Therefore, the firms were asked whether a member of the firm's management team had work experience abroad or whether a manager was educated abroad before joining the company. These factors can also be regarded as constituting an intangible asset decisive in determining firms' internationalisation behaviour from a resource based view of the firm. However, not only previous experience but also and in the first line integral capabilities and skills possessed by members of the management team are likely to increase the probability of an international engagement. Therefore, the firms' representatives were asked to indicate on a five point Likert scale whether they experience a shortage of skills in different areas, among them sales, distribution, production, and R\&D. The econometric model will include two dummy variables taking the value 1, if a firms' managers experience a “serious" (4) or a "very serious shortage” (5) in sales/distribution and production/R\&D, respectively. These two variables also reflect the entrepreneurial perspective developed by Andersson (2000). The absence of a serious shortage in sales and distribution may indicate that the managers in question are behaving like marketing entrepreneurs who proactively create the internationalisation process for their firm. On the contrary, the absence of a shortage in production or R\&D may hint at the involvement of a technical entrepreneur, who is mainly interested in technology and the development of the production process.

Moreover, the econometric model includes two dummy variables that signify whether a firm is sited in West Germany and East Germany, respectively. The empirical analyses based on the cross section of the first survey revealed a significantly positive marginal effect on the Western German firms' propensity to internationalise compared with Eastern German and UK firms, whereas there was no difference between Eastern German and UK firms (see Bürgel et al. 2004). Hence, I distinguish not only between German and UK firms but also between West and East German firms in order to reconsider the effect observed in the first survey. Finally, I add industry dummies to the estimation equation. As Table 2 shows, in the manufacturing sectors ICT-hardware and health/life 
sciences almost $100 \%$ of the firms had international sales in 1997 and 2003. Including a dummy variable for the manufacturing sector health/life sciences thus leads to the inclusion of a variable that perfectly predicts the international engagement of firms in this sector. Hence, I include only three dummy variables each for the sectors engineering and ICT-hardware ${ }^{23}$, and a combined dummy variable for the sector health/life sciences and for other high-tech manufacturing industries, thus using the software/service industry as the base category.

\section{Empirical Results}

The results of the empirical model are given in Table $4 .{ }^{24}$ The second column shows the vector of coefficients $\hat{\beta}_{01}$, explaining the transition from the status "non-exporter" at time $t-1$ to the status “exporter” at time $t$, i.e., foreign market entry. The third column includes the vector $\tilde{\beta}_{11}$, which discriminates between firms that stay in the international market (transition from status "exporter" to status "exporter") and firms that exit from the international market. Remember that the coefficient vectors $\beta_{00}$ and $\beta_{10}$ were set to 0 in order to identify the model.

An appreciation of the industry real exchange rate reduces the probability of entering the foreign market. Conversely, the exchange rate has no effect on probability of exit. This result is consistent with the existence of sunk costs: A depreciation of the domestic currency increases the number of exporting firms, but a subsequent appreciation does not reduce the number of exporters by the same amount because, once entered, firms continue exporting in order to avoid re-entry costs. However, since the firms were observed only twice with a six year interval between the two surveys, the results do not prove the sunk costs hypothesis but are consistent with the theory of sunk costs and other empirical studies (e.g., Roberts and Tybout 1997, Bernard and Jensen 2001).

23 As mentioned above, the dependent variable in the logit models is the transition between different states of internationalisation. Due to some missing values in the independent variables, we have not observed firms with varying transitions in the sector health/life sciences. This is not the case for ICT-hardware firms, thus the respective dummy variable is not a perfect predictor.

24 The results were obtained using the statistical software package STATA, version 7 SE. The estimator of the rare events logit, programmed by Michael Tomz, Gary King, and Langche Zeng, is available at http://GKing.Harvard.Edu (cf. King and Zeng 2001). For analysing the results, I further used the STATA based programme CLARIFY, written by Michael Tomz, Jason Wittenberg, and Gary King, and also available at http://GKing.Harvard.Edu (cf. King et al. 2000). 


\begin{tabular}{|c|c|c|c|c|c|c|}
\hline & \multicolumn{3}{|c|}{$\begin{array}{c}\text { Transition } \\
\text { non-exporter } \rightarrow \text { exporter }\end{array}$} & \multicolumn{3}{|c|}{$\begin{array}{c}\text { Transition } \\
\text { exporter } \rightarrow \text { exporter }\end{array}$} \\
\hline & \multicolumn{3}{|c|}{ Logit model } & \multicolumn{3}{|c|}{ Rare events logit } \\
\hline & \multicolumn{3}{|c|}{$\begin{array}{c}\text { Number of observations }=150 \\
\qquad L \mathrm{~L}=-67.953 \\
\chi^{2}(17)=48.12 \\
\text { Prob }>\chi^{2}(17)=0.000 \\
\text { McFadden's } \mathrm{R}^{2}=0.307\end{array}$} & \multicolumn{3}{|c|}{$=0}$. \\
\hline & \multicolumn{3}{|c|}{$\begin{array}{l}\text { Robust } \\
\text { stand. error }\end{array}$} & Coeff. & $\begin{array}{c}\text { Robust } \\
\text { stand. erro }\end{array}$ & \\
\hline Industry real exchange rate & -0.360 & 0.017 & $* *$ & 0.158 & 0.022 & \\
\hline West Germany & -0.696 & 0.583 & & 0.329 & 0.839 & \\
\hline East Germany & -1.387 & 0.640 & $* *$ & -0.982 & 0.965 & \\
\hline Engineering & 0.828 & 0.593 & & 1.787 & 0.917 & $*$ \\
\hline ICT-Hardware & 2.576 & 1.193 & $* *$ & 0.419 & 1.159 & \\
\hline Other manufacturing industries & 1.466 & 0.592 & $* *$ & 0.830 & 0.807 & \\
\hline Log (number of employees) & 1.228 & 0.279 & $* * *$ & 0.566 & 0.335 & $*$ \\
\hline Log (age) & 0.604 & 0.557 & & -0.790 & 0.753 & \\
\hline $\mathrm{R} \& \mathrm{D}$ intensity & 0.052 & 0.028 & $*$ & 0.057 & 0.035 & $*$ \\
\hline Tried and tested technology & -0.041 & 0.497 & & -0.297 & 0.646 & \\
\hline Working experience abroad & 0.837 & 0.475 & $*$ & 0.675 & 0.790 & \\
\hline Education abroad & -0.710 & 0.750 & & 1.553 & 0.790 & $* *$ \\
\hline \multicolumn{7}{|l|}{ Shortage in competencies } \\
\hline Sales/distribution & 0.089 & 0.516 & & 0.153 & 0.595 & \\
\hline Production/R\&D & -0.915 & 0.596 & & 0.071 & 0.700 & \\
\hline Intense product customisation & -1.168 & 0.491 & $* *$ & -1.749 & 1.056 & $*$ \\
\hline Regular maintenance and upgrades & -0.260 & 0.460 & & -0.691 & 0.724 & \\
\hline Consumer good & -0.556 & 0.501 & & 0.584 & 0.723 & \\
\hline
\end{tabular}

$* 10 \%$ level of significance; ** $5 \%$ level of significance; *** $1 \%$ level of significance.

a The value of the log-likelihood function and McFadden's $\mathrm{R}^{2}$ are not reported since the rare event logit is an unbiased estimator and not a likelihood technique. Thus, it does not maximize a likelihood function. Base category: UK software firm using "novel technology” with arrival status "non-exporter".

Source: own estimation.

The country-specific dummy variables reveal a lower probability of East German firms entering the foreign market than both West German and UK firms. East German firms in our sample were founded shortly after German reunification. Foreign trade in former East Germany was traditionally oriented towards Eastern Europe and all East German firms have had to learn how to access Western European markets. Of course, since the firms in our sample are newly founded firms, each individual firm had to investigate potential foreign markets in order to reduce the uncertainty of their first entry - whether they are sited in East Germany, in West Germany, or in the UK. However, West German and UK firms may profit from regional spillover effects that reduce the 
costs of entry into the foreign market that do not exist in Eastern Germany. In particular, the presence of multinational firms may increase the availability of specialised capital and labour inputs, thereby facilitating foreign market entry for future exporters (Aitken et al. 1997). In Eastern Germany, multinational firms were absent at least in the first years after German reunification. On the other hand, once firms have overcome the barrier presented by their first foreign market entry, there is no significant difference with respect to market exit among firms from West Germany, East Germany, and the UK. ${ }^{25}$

Comparing these results with the estimated propensity to internationalise from the first survey, we see that in contrast to earlier results ${ }^{26}$, West German firms no longer have a higher probability of exporting than UK firms. Thus, when regarding a longer time period, the difference between West German and UK firms that was observed during the firms' early stages disappears.

Firms from the manufacturing sectors ICT-hardware and other manufacturing industries (including health/life sciences) are more likely to enter the foreign market than engineering and software firms. Software and service firms often offer their services locally, acting as contract developers for larger firms. The lower probability of foreign market entry by software/service firms is consistent with the descriptive statistics in Table 2. Surprisingly and in contrast to the descriptive analysis, engineering firms differ from the two other manufacturing sectors. They also have a lower probability of entering the foreign market. Possibly, there are industry specific entry costs that are not captured by the remaining firm-specific variables. High entry costs might hamper engineering firms in starting to export. Given the earlier descriptive results showing that the share of engineering firms with international sales is comparable to that of the other manufacturing sectors, we might conclude that engineering firms are better equipped with assets that enhance their international business activities, enabling them to overcome the possibly high industry-specific entry barriers. The existence of high entry costs in engineering industries is also supported by the estimated exit probability. Engineering firms have a lower probability of exiting from the international market than all other industry sectors. If there are high entry costs, engineering firms tend to avoid these high industry-specific re-entry costs by staying in the international market. On the other hand, if re-entry costs do not vary significantly among the other industries, firms will leave the

25 Bernard and Jensen (2001) tested for geographical spillover effects in the US manufacturing industry, but did not find any evidence of the existence of spillover effects that were hypothesised to reduce entry costs. According to the authors, this may result from the exclusive selection of large manufacturing plants.

26 In this section, it often seems reasonable to compare the empirical results of this paper with the results of the crosssectional analyses of the first survey. The results of the first survey are given in Bürgel et al. (2004); I refer to this report, although I do not mention it explicitly in each case. 
international market with the same probability. This includes software firms once they have entered the foreign market.

As predicted by the internationalisation process model, larger firms, measured by the logarithm of number of employees, are more likely to enter the international market. We should, however, be careful when interpreting the correlation between firms' export behaviour and firm size. The causality between exporting and performance is a matter of intense empirical discussion. A large firm size can be regarded as an outcome of good firm performance in the past. Bernard and Jensen (1999) appropriately entitled their paper "Exceptional Exporter Performance: Cause, Effect, or Both?”. The result of this paper is very clear-cut: “Good plants become exporters”, (Bernard and Jensen 1999, p. 23). ${ }^{27}$ Taking this result as given, the empirical specification of the present paper is correct: An above-average employment growth rate prior to the time of the survey, which typically leads to a higher observed number of employees, causes a higher probability of entering the international market. The direction of causality is beyond the scope of this paper. Nevertheless, we might suspect that the very clear result that good firms become exporters will not hold for our sample of young high-tech firms, since we observe a fairly high number of firms that have exported since start-up ("born globals”). It is simply not possible for born globals to have grown faster in the years prior to the start of their international activities as in the case of the US manufacturing firms studied by Bernard and Jensen. Thus, the estimated positive correlation between firm size and international business activities in this paper might reflect reverse causality or a feedback relationship between these two variables, making firm size endogenous in the above regression.

The relationship between firm size and the predicted probability of entering the foreign market is depicted by the upper left graph in Figure 1 in the appendix. Setting all other variables to their mean, the graph clearly reflects the positive correlation between number of employees and (predicted) propensity to internationalise. The graph only has a relatively steep slope where the number of employees is small. The predicted probability of entering exceeds $80 \%$ at 17 employees. The graph becomes flat thereafter, nearly reaching a $100 \%$ probability of starting exports for firms with more than 100 employees. If a minimum size for international business activities exists, it is quite low and already exceeded by the average firm in our sample. ${ }^{28}$

27 This result is confirmed, for example, by Bernard and Wagner (1997), Clerides et al. (1998), and Arnold and Hussinger (2004).

28 Recall that the average firm of our sample had 19 employees in 1997 and 26 in 2003 (see section 3). 
Firm size not only positively affects the probability of foreign market entry, it is also correlated with a higher persistence in firms' exporting activities, i.e., large firms are less likely to exit from the foreign market than small firms. This result can be interpreted in two ways: Firstly, shrinking firms may stop exporting because they no longer have enough resources to carry out international business activities. Alternatively, an exit from the international market may cause a drop in the number of employees, e.g., because firms may no longer be exposed to international competition and best practise technology, or because an exit may signal failure to domestic customers (McKinsey 1993b, Bernard and Wagner 1997). As before, it is beyond the scope of this paper to analyse the direction of causality. In the literature, the relationship between foreign market exit and the development of employment is practically neglected. One exception is the study of Girma et al. (2003) on UK firms. Applying matching techniques, they discovered that employment and output drop in the year of exit and in the two subsequent years, while total factor productivity does not decrease after exit. For German plants, Bernard and Wagner (1997) also noted a significant drop in employment after exiting from the foreign market.

The upper right graph in Figure 1 depicts the predicted probability of staying in the international market in dependence of the number of employees, with all other variables set to their mean. Since a market exit constitutes a rare event in our data, the predicted probability of remaining an exporter is high, in most cases exceeding $90 \%{ }^{29}$ The graph shows that only firms with less than approximately 10 employees have a significantly lower probability of continuing to exporting. Interestingly, if international business activities require a minimum size, the threshold for staying in the foreign market is even smaller than the threshold for market entry. Once the firms have paid sunk entry costs like accessing information on foreign markets or setting up foreign sales channels, operating costs in the foreign market can in general be borne even by very small firms.

Firm age has no significant effect on the transition probabilities. This result contradicts the stage models of internationalisation. Interestingly, the cross-sectional analysis of the first survey resulted in a positive influence of firm age on the propensity of internationalisation. Obviously, when regarding a longer time period, firm age is no longer relevant, probably because the surveyed firms

29 Setting all independent variables, including number of employees, to their mean, the predicted probability of remaining an exporter in the rare event logit model is $93.31 \%$. In comparison, applying the conventional logit model, i.e., without the correction described in section 4 , results in a predicted probability of $98.06 \%$. The observed share of transitions with an arrival status "exporter" is $90.27 \%$. Thus, both models, the rare event logit and the conventional logit model, overestimate the probability of the more frequent event and underestimate the rare event of foreign market exit if all independent variables are set to their mean. However, the difference is clearly smaller for the rare event logit model, which justifies the choice of applying the rare event logit estimator. 
are now an average of 12 years and no longer belong to what is in general defined as newly founded technology-oriented firms (see section 3). For "mature" high-tech firms, firm age seems unable to discriminate between exporters and non-exporters. The relationship between firm age and foreign market entry and exit is displayed in detail by Figure 1 in the appendix. Although the probability of market entry is positively correlated with firm age, reflecting an expansion of international business activities as the firms grow older, the prediction of market entry in the first years after firm foundation is associated with a high uncertainty. The predicted probability of remaining an exporter has a negative slope. This is, however, a result of the composition of our sample: Nearly all exits from the foreign market occur between the 1997 and the 2003 surveys. In 2003, the firms were at least 7 years old. Only one firm left the foreign market between start-up and 1997. Thus, for young firms, we only observe transitions from the status of exporter to the status of exporter, resulting in a negative but insignificant coefficient.

The share of $R \& D$ expenditures to total sales is positively significant in both columns in Table 4, indicating a higher chance of arrival status "exporter" for firms that invest intensively in R\&D. R\&D activities can be expected to create assets within a firm that are difficult to imitate by the firm's rivals. This facilitates the firm's internationalisation process as predicted by the resource based view of the firm. The positive relationship between $R \& D$ intensity and the predicted probabilities of transition can also be seen in the lower graphs of Figure 1. The coefficient of the second variable, included in the estimation equation to approximate the innovativeness of the firms' production processes (dummy for "tried and tested technology"), shows the expected sign but is not significant at any conventional level. Since both variables are intended to approximate the firms' innovative production processes, the effect of applying a "novel technology" (the base category of "tried and tested technology") might already be covered by the R\&D intensity. Moreover, it can be argued that a dummy variable indicating those firms that produce with tried and tested technology is no longer suitable to discriminate between firms as was the case for the cross section of the first survey - at least for UK firms. In 2003, the share of firms that produced with a tried and tested technology was significantly smaller than it was in the cross section of the first survey. Firms that participated in both surveys often changed their production technology from a tried and tested technology to a novel technology between 1997 and 2003. ${ }^{30}$ Hence, this variable has no more discriminatory power.

30 Although this is beyond the capacity of our data to prove, it is consistent with our results that using a novel technology was a prerequisite to survive until 2003. 
All cited theories from the field of international management emphasize the role of experienced managers in the internationalisation process. The results show that managers who acquired international experience before entering the firm facilitate the firm's international business activities: If one member of the management team has work experience abroad, the firm is more likely to enter the foreign market. Similarly, if at least one manager was educated abroad, his firm is less likely to exit from the foreign market. Entering a foreign market obviously requires the firm's manager to be familiar with foreign business practices and market conditions that can be best acquired by working abroad. A permanent international engagement, however, can be better assured by managers that have living experience abroad, gained while studying in a foreign country. Managers with living experience abroad are able to assess preferences and needs of foreign customers, allowing them to develop long-term business relations. These results support both the internationalisation process model, which states that an internationally experienced management team can overcome the uncertainty present in foreign markets, and the resource based view of the firm that regards international experience as an intangible asset that differentiates firms from their competitors. On the other hand, the entrepreneurial perspective of the firm cannot explain foreign market entry and exit. The (absence of) shortages in sales/distribution and production/R\&D are not significant in either of the two coefficient vectors. Performing a Wald test of joint significance does not reveal any significant effect of the dummy variables of shortages in competencies either (transition from non-exporter to exporter: $\chi^{2}(2)=2.37$, [Prob $>\chi^{2}$ ] $=0.306$; transition from exporter to exporter: $\chi^{2}(2)=0.08$, [Prob $\left.\left.>\chi^{2}\right]=0.959\right)$.

As expected, intense customisation is a barrier for international business activities. Even firms that have exports tend to exit from the foreign market, probably because they have underestimated the costs that arise from their product's high customisation requirements. The necessity of regular maintenance and upgrades, on the other hand, does not show any effect on firms' exporting activities. Furthermore, to whom the product is sold is not important. The dummy variable identifying the product as a consumer good or service is also not significant. Hence, assessing the chances and risks of an international engagement should not be done by identifying a typical customer of a firm's product, but by evaluating the product's transaction costs, especially the need of individual client customisation.

The empirical model fits well with the data. In the logit model explaining the determinants of a transition from the status “non-exporter” to the status “exporter”, McFadden’s R² reaches a value of 0.307 . This value is quite high, indicating that a large part of firm-specific heterogeneity is in fact apparent and able to discriminate between exporters and non-exporters. For the rare events logit model that determines the probability of staying an exporter, however, McFadden's $\mathrm{R}^{2}$ is not 
of much use, because the rare event logit is an unbiased estimator that does not maximize a likelihood function. In fact, the rare event logit estimator fits the data worse than the ordinary logit model, but the former has a smaller mean square error.

\section{Conclusion}

In order to fulfil the expectations put on them with respect to growth and job creation, newly founded technology based firms have to achieve continuous long-term growth. It is often argued that sales potential in European domestic markets is insufficient for the amortisation of high product research and development costs so that long-term international business activities are seen as decisive for growth perspectives of NTBFs. This paper focuses on long-term internationalisation behaviour as a potential basis for long-term firm development, although the relation of firm performance and internationalisation is left for future research. I have investigated a longitudinal data set of about 200 German and British technology-oriented firms that were founded in the period between 1987 and 1996, inclusive. The firms were contacted using two surveys conducted in 1997 and 2003. The first conclusion of this study is that German and UK firms are broadly similar with respect to their internationalisation behaviour. With the exception that East German firms enter the foreign market with a lower probability, I have not found significant differences between the two countries.

The second result of this study already becomes apparent due to the descriptive analysis. Although there is a high persistence in the firms' international business activities, we observe entry into and exit from the foreign market. Only $15 \%$ of the firms in our sample have never had international sales. The phenomenon of non-persistent export participation trajectories has already been highlighted by Roberts and Tybout (1997) and confirmed, among others, by Bernard and Jensen (2001). Analysing long-term international business activities, therefore, requires examining both entry and exit. However, the theories from the field of international management that were described in this paper and that were used to identify firm-specific variables that may influence firms' internationalisation behaviour (stage models of internationalisation, the entrepreneurial perspective of internationalisation) are limited to foreign market entry. This paper extends this restricted view by examining empirically firm-specific characteristics that are able to discriminate between firms that enter the foreign market and firms that eschew it, and, additionally, to discriminate between firms that exit from the foreign market and those that remain internationally active. Understanding why firms enter and exit the foreign market will help future research explain the relation of performance to international business activities. 
Previous empirical studies of firms' export activities have focused on sunk costs as the main reason for the observed persistence in export behaviour. Although our data set is not suitable to prove empirically the existence of sunk costs, our results are consistent with the sunk costs hypothesis. We not only observe a high persistence in the internationalisation status which can be expected if sunk costs are relevant. Some results of the logit regressions can also best be interpreted by assuming the existence of sunk costs. Further, the effect of the industry real exchange rate is consistent with the sunk cost hypothesis: Depreciation of domestic currency promotes foreign market entry, but appreciation has no significant effect on exit, probably because firms continue to export in order to avoid re-entry costs.

Sunk costs present a barrier to entering the international market. The ability of a firm to overcome this barrier is influenced by the firm's idiosyncratic bundle of assets as predicted by the resource based view of the firm and with support from the data. In particular, the results highlight the strategic role of investment in $R \& D$. R\&D activities generate assets by which a firm distinguishes itself from its rivals. These assets not only facilitate foreign market entry, but also support a longterm engagement in the international market. Firms that had never had international sales before 2003 and firms that had exited from the foreign market spent a significantly smaller share of total sales on R\&D in 2003, as shown by the descriptive analysis. Since all of the firms in our sample operate in high-tech sectors, the firms' R\&D activities constitute an essential asset that discriminates between firms and correlates with their international business activities. In addition to R\&D intensity, the international experience of firms' managers is an important asset that helps firms internationalise. Interestingly, foreign market entry and exit depend on different knowledge: Whereas market entry requires managers' familiarity with foreign business practices, staying in the foreign market is supported by managers who are able to assess preferences and needs of foreign customers.

Finally, the success of a firm's international engagement depends on the characteristics of its product. High client-specific product customisation is a barrier to entry into the foreign market. If a firm has to consider the special needs of each customer, it will be difficult to realise economies of scale and fully profit from the foreign market's sales potential. Firms that had entered the foreign market with a product requiring intensive product customisation have often stopped exporting, likely because they recognized that exporting was not profitable for them. Exporting a customised product may only be profitable if a firm can sell its product to a limited number of key foreign customers that represent sufficient sales potential for the supplying firm. 


\section{References}

Aitken, B., G. H. Hanson, and A. E. Harrison (1997), Spillovers, Foreign Investment, and Export Behavior, in: Journal of International Economics, 43 (1-2), 103-132.

Andersson, S. (2000), The Internationalization of the Firm from an Entrepreneurial Perspective, in: International Studies of Management and Organisation, 30, 63-92.

Arnold, J. M., and K. Hussinger (2004), Export Behavior and Firm Productivity in German Manufacturing, ZEW Discussion Paper No. 04-12, Mannheim.

Baldwin, R. E. (1988), Hysteresis in Import Prices: The Beachhead Effect, in: American Economic Review, 78 (4), 773-785.

Baldwin, R. E., and P. R. Krugman (1989), Persistent Trade Effects of Large Exchange Rate Shocks, in: Quarterly Journal of Economics, 104 (4), 635-654.

Bernard, A. B., and J. B. Jensen (1999), Exceptional Exporter Performance: Cause, Effect, or Both?, in: Journal of International Economics, 47, 1-25.

Bernard, A. B., and J. B. Jensen (2001), Why Some Firms Exports, National Bureau of Economic Research, Working Paper No. 8349, Cambridge, MA.

Bernard, A. B., and J. Wagner (1997), Exports and Success in German Manufacturing, in: Review of World Economics, 133 (1), 134-157.

Bernard, A. B., and J. Wagner (2001), Export Entry and Exit by German Firms, in: Review of World Economics, 137 (1), 105-123.

Bilkey, W. J. (1978), An Attempted Integration of the Literature on the Export Behavior of Firms, in: Journal of International Business Studies, 9 (1), 33-46.

Bilkey, W. J., and G. Tesar (1977), The Export Behavior of Small-Sized Wisconsin Manufacturing Firms, in: Journal of International Business Studies, 8 (1), 93-98.

Bürgel, O., A. Fier, G. Licht, and G. Murray (2004), The Internationalisation of Young High-Tech Firms, ZEW Economic Studies, 22, Heidelberg, New York.

Butchart, R. (1987), A New UK Definition of High-Technology Industries, in: Economic Trends, 400, 82-88.

Clerides, S. K., S. Lach, and J. R. Tybout (1998), Is Learning by Exporting Important? MicroDynamic Evidence from Colombia, Mexico, and Morocco, in: The Quarterly Journal of Economics, 113 (3), 903-947.

Dixit, A. (1989a), Entry and Exit Decisions under Uncertainty, in: Journal of Political Economy, 97 (3), 621-638.

Dixit, A. (1989b), Hysteresis, Import Penetration, and Exchange Rate Pass-Through, in: Quarterly Journal of Economics, 104 (2), 205-228.

Dunning, J. H. (1993), Multinational Enterprises and the Global Economy, Wokingham: Addison-Wesley.

European Commission (2002), High-Tech SMEs in Europe, in: Observatory of European SMEs, No. 6, Luxembourg.

Girma, S., D. Greenaway, and R. Kneller (2002), Does Exporting Lead to Better Performance? A Microeconometric Analysis of Matched Firms, University of Nottingham, GEP Research Papers No. 02/09, Nottingham. 
Girma, S., D. Greenaway, and R. Kneller (2003), Export Market Exit and Performance Dynamics: A Causality Analysis of Matched Firms, in: Economics Letters, 80, 181-187.

Gouriéroux, Ch. (2000), Econometrics of Qualitative Dependent Variables, Cambridge Univ. Press, Cambridge, originally published as: Econométrie des variables qualitatives (1991), second edition, Economica.

Honoré, B. E., and E. Kyriazidou (2000), Panel Data Discrete Choice Models with Lagged Dependent Variables, in: Econometrica, 68 (4), 839-874.

Johanson, J., and J.-E. Vahlne (1977), The Internationalization Process of the Firm - a Model of Knowledge Development and Increasing Market Commitments, in: Journal of International Business Studies, 8 (1), 23-32.

Johanson, J., and J.-E. Vahlne (1990), The Mechanism of Internationalisation, in: International Marketing Review, 7 (4), 11-24.

Karshenas, M., and P. Stoneman (1993), Rank, Stock, Order, and Epidemic Effects in the Diffusion of New Process Technologies: An Empirical Model, in: Rand Journal of Economics, 24 (4), 503-528.

King, G., M. Tomz, and J. Wittenberg (2000), Making the Most of Statistical Analyses: Improving Interpretation and Presentation, in: American Journal of Political Science, 44 (2), 341-355.

King, G., and L. Zeng (2001), Logistic Regression in Rare Events Data, in: Political Analysis, 9 (2), 137-163.

Krugman, P. R. (1989), Exchange-Rate Instability, Cambridge, MA: MIT Press.

Lautanen, T. (2000), Modelling Small Firms’ Decisions to Export - Evidence from Manufacturing Firms in Finland, 1995, in: Small Business Economics, 14, 107-124.

Lindqvist, M. (1991), Infant Multinationals: The Internationalization of Young, Technology-Based Swedish Firms, Stockholm School of Economics, Institute of International Business, Stockholm.

Little, A. D. (1977), New Technology-Based Firms in the United Kingdom and the Federal Republic of Germany, Anglo-German Foundation for the Study of Industrial Society, London, Bonn.

Madhok, A. (1997), Cost, Value and Foreign Market Entry Mode: The Transaction and the Firm, in: Strategic Management Journal, 18, 39-61.

McCullagh, P., and J. A. Nelder (1989), Generalized Linear Models, second edition, New York: Chapman and Hall.

McDougall, P. P., S. Shane, and B. M. Oviatt (1994), Explaining the Formation of International New Ventures: The Limits of International Business Research; in: Journal of Business Venturing, 9, 469-489.

McDougall, P. P., and B. M. Oviatt (2000), International Entrepreneurship: the Intersection of Two Research Paths, in: Academy of Management Journal, 43 (5), 902-906.

McKinsey and Company (1993a), Emerging Exporters: Australia's High Value-Added Manufacturing Exporters, Melbourne: Australian Manufacturing Council.

McKinsey Global Institute (1993b), Manufacturing Productivity, Washington, D.C.: McKinsey and Company.

Oviatt, B. M., and P. P. McDougall (1994), Toward a Theory of International New Venture, in: Journal of International Business Studies, 25 (1), 45-64. 
Penrose, E. (1959), The Theory of the Growth of the Firm, Oxford: Basil Blackwell.

Prantl, S. (2001), Bankruptcy, Subsidized Loans, and Exit Decisions of Start-Up Firms, University of Mannheim, Dissertation, Mannheim.

Reid, S. (1983), Firm Internationalization, Transaction Costs and Strategic Choice, in: International Marketing Review, 1 (2).

Roberts, M. J., and J. R. Tybout (1997), The Decision to Export in Columbia: An Empirical Model of Entry with Sunk Costs, in: The American Economic Review, 87 (4), 545-564.

Stoneman, P. (1983), The Economic Analysis of Technological Change, Oxford: Oxford University Press.

Storey, D. J., and B. Tether (1996), A Review of the Empirical Knowledge and an Assessment of Statistical Data on the Economic Importance of New Technology-Based Firms in Europe, Coventry: Warwick Research Institute.

Teece, D. J., G. Pisano, and A. Shuen (1997), Dynamic Capabilities and Strategic Management, in: Strategic Management Journal, 18 (7), 509-533.

Van Phu, N., U. Kaiser, and F. Laisney (2000), The Performance of German Firms in the Business-Related Service Sectors: A Dynamic Analysis, ZEW Discussion Paper No. 00-32, Mannheim.

Wernerfelt, B. (1984), A Resource-Based View of the Firm, in: Strategic Management Journal, 5, 171-180.

Williamson, O. E. (1985), The Economic Institutions of Capitalism, New York: Free Press. 


\section{Appendix}

Table 5: Definition of High-tech Sectors

\begin{tabular}{|c|c|c|}
\hline $\begin{array}{l}\text { Aggregated } \\
\text { industries used }\end{array}$ & NACE Rev. 1 & Short description according to NACE Rev.1 \\
\hline $\begin{array}{l}\text { R\&D Intensive } \\
\text { Service Industries }\end{array}$ & $\begin{array}{l}64.20 ; 72.20 \\
72.30 ; 72.40 \\
72.60 ; 73.10\end{array}$ & $\begin{array}{l}\text { Telecommunication, Computer Programming and Software Services, Data } \\
\text { Processing, Misc. Computer Services, R\&D in Natural Sciences and Engi- } \\
\text { neering }\end{array}$ \\
\hline ICT-Hardware & $\begin{array}{l}30.01 ; 30.02 \\
32.20 ; 32.30\end{array}$ & $\begin{array}{l}\text { Office Equipment; Computers and other Information Processing Equipment; } \\
\text { Television and Radio Transmitters and Apparatus for Line Telephony and } \\
\text { Line Telegraphy; Television and Radio Receivers, Sound or Video Re- } \\
\text { cording and Reproducing Apparatus }\end{array}$ \\
\hline $\begin{array}{l}\text { Engineering } \\
\text { Industries }\end{array}$ & $\begin{array}{l}33.20 ; 33.30 \\
33.40\end{array}$ & $\begin{array}{l}\text { Electronic Instruments and Appliances for Measuring, Checking (except } \\
\text { Industrial Process Control); Electronic Industrial Process Control Equipment, } \\
\text { Optical Instruments; Photographic Equipment }\end{array}$ \\
\hline $\begin{array}{l}\text { Health and Life } \\
\text { Sciences }\end{array}$ & $\begin{array}{l}24.41 ; 24.42 ; \\
33.10\end{array}$ & $\begin{array}{l}\text { Pharmaceutical Products and Preparations; Medical and Surgical Equipment } \\
\text { and Orthopaedic Appliances }\end{array}$ \\
\hline $\begin{array}{l}\text { Other High-tech } \\
\text { Manufacturing }\end{array}$ & $\begin{array}{l}24.16 ; 24.17 \\
31.10 ; 31.20 \\
32.10 ; 35.30\end{array}$ & $\begin{array}{l}\text { Plastics and Synthetic Rubber in Primary Form; Electric Motors, Generators } \\
\text { and Transformers; Electricity Distribution and Control Apparatus; Electronic } \\
\text { Valves, Tubes and other Components; Aircraft and Spacecraft Manufactur- } \\
\text { ing }\end{array}$ \\
\hline
\end{tabular}

Source: Manufacturing sector: Butchart (1987); service sector: Bürgel et al. (2004).

Table 6: Sample Composition of the Population of High-tech Firms 1997 and 2003

\begin{tabular}{l|cc|c|cc|c}
\hline \multirow{2}{*}{ Employees } & \multicolumn{3}{|c|}{ Surviving firms 1997 } & \multicolumn{3}{c}{ Surviving firms 2003 } \\
\hline Germany & Manufacturing & Services & Total & Manufacturing & Services & Total \\
\hline $3-5$ & & & & & \\
6-9 & 637 & 1,241 & 1,878 & 508 & 359 & 1,467 \\
$10-19$ & 401 & 654 & 1,055 & 338 & 517 & 855 \\
$20+$ & 525 & 596 & 1,121 & 437 & 463 & 900 \\
\hline Total & 621 & 370 & 991 & 515 & 269 & 784 \\
\hline UK & 2,184 & 2,861 & 5,045 & 1,798 & 2,208 & 4,006 \\
\hline $3-5$ & & & & & & 643 \\
$6-9$ & 673 & 742 & 1,415 & 581 & 286 & 6,224 \\
$10-19$ & 475 & 369 & 844 & 405 & 210 & 621 \\
$20+$ & 472 & 292 & 764 & 411 & 141 & 418 \\
\hline Total & 362 & 177 & 539 & 277 & 1,280 & 2,954 \\
\hline \hline
\end{tabular}

Remark: The 1997 assignment of a single firm to a stratification cell was used.

Source: ZEW, University of Exeter. 
Figure 1: Predicted Probability of Transition

Transition non-exporter $\rightarrow \operatorname{exporter}(0 \rightarrow 1)$

Transition exporter $\rightarrow$ exporter $(1 \rightarrow 1)$

Predicted probability in dependence of the number of employees
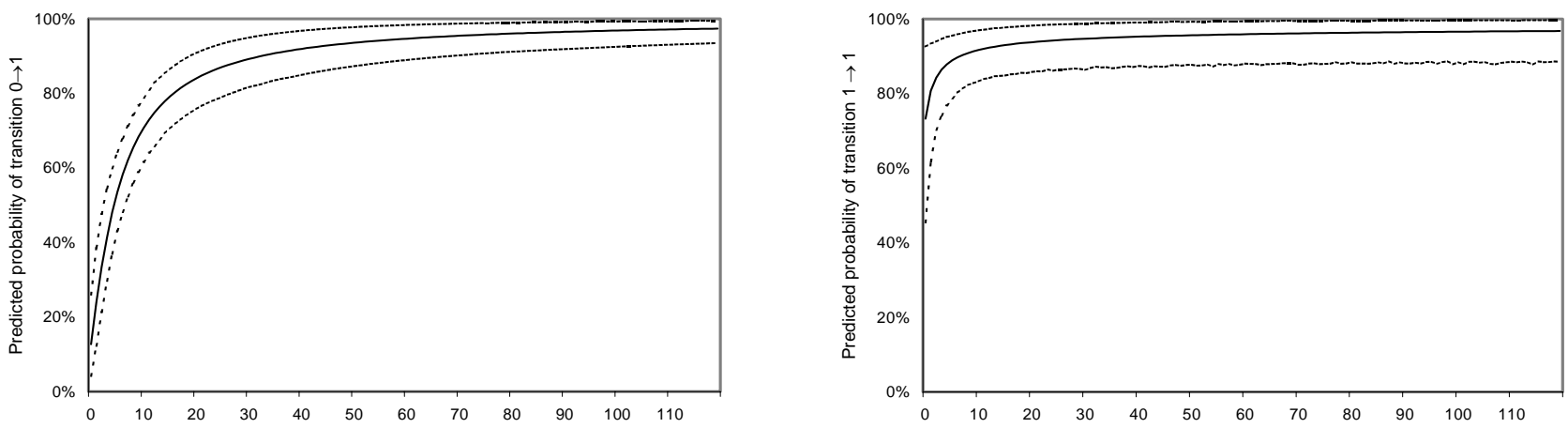

Predicted probability in dependence of firm age (in years)
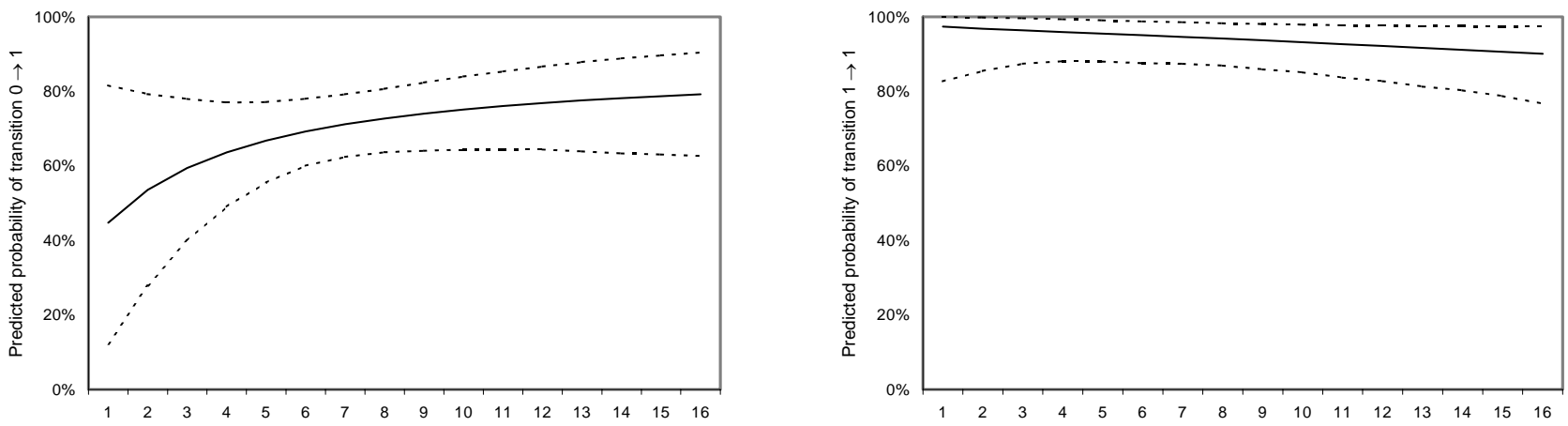

Predicted probability in dependence of R\&D intensity (in \%)
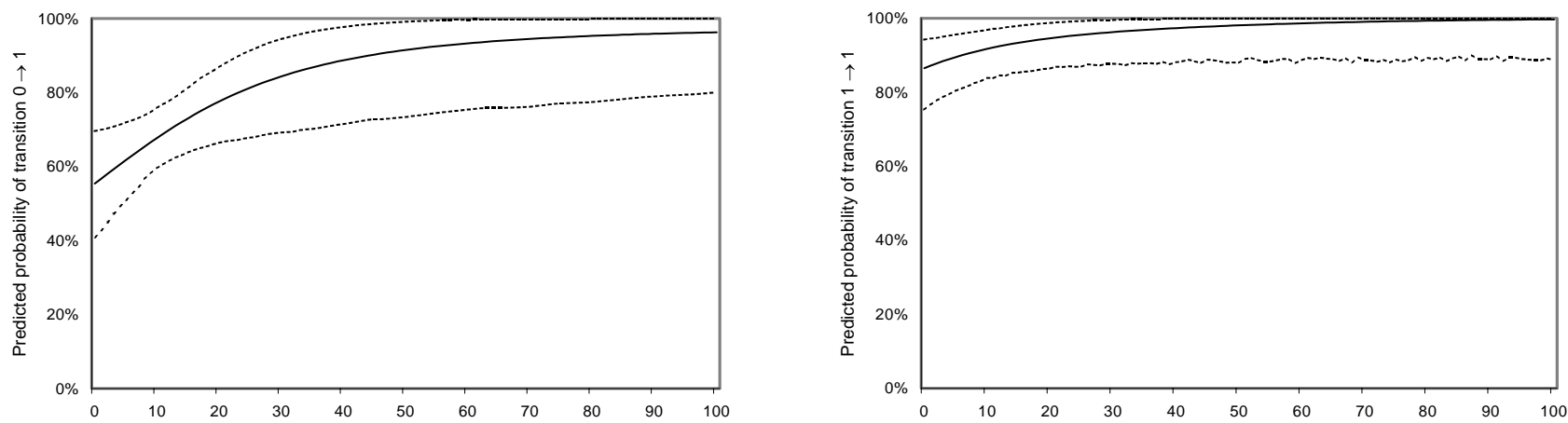

Solid line: predicted probability of transition in dependence of the continuous variable, all other variables set to their mean.

Dotted lines: simulated $90 \%$ confidence interval, using 1,000 simulations for the transition from the status of non-exporter to the status exporter (left column) and 10,000 simulations for the transition from the status exporter to the status exporter (right column). Source: own calculation. 